\title{
Effects of a reduction of diet crude protein content on gaseous emissions from deep-litter pens for fattening pigs
}

\author{
François-Xavier PHILIPPE, Martine LAITAT, Bernard CANART, \\ Frédéric FARNIR, Laurent MASSART, Marc VANDENHEEDE, \\ Baudouin NICKS*
}

\begin{abstract}
University of Liège, Faculty of Veterinary Medicine, Department of Animal Productions, boulevard de Colonster, B43, 4000 Liège, Belgium
\end{abstract}

(Received 13 June 2005 - Accepted 16 May 2006)

\begin{abstract}
Two successive batches of 32 fattening pigs per batch were each divided into 2 homogenous groups of 16 pigs fed either a high crude protein (CP) level diet (HP-groups) or a low crude protein level diet balanced with synthetic amino acids (LP-groups). Pigs were raised on strawbased deep litters in separate rooms according to diets. Once a month, the emissions of ammonia $\left(\mathrm{NH}_{3}\right)$, nitrous oxide $\left(\mathrm{N}_{2} \mathrm{O}\right)$, methane $\left(\mathrm{CH}_{4}\right)$, carbon dioxide $\left(\mathrm{CO}_{2}\right)$ and water vapour $\left(\mathrm{H}_{2} \mathrm{O}\right)$ were measured continuously for 6 days consecutively. The mean nitrogen $(\mathrm{N})$ intakes of pigs from HPgroups and LP-groups were $6.83 \mathrm{~kg}$ and $5.78 \mathrm{~kg}$ per pig respectively with mean initial and final pig body weights of 26.6 and $111.4 \mathrm{~kg}$. There was no significant difference between the daily weight gains with regards to the diet $\mathrm{CP}$ content. At the end of the fattening periods, the $\mathrm{N}$-contents of the litters were on average $1.84 \mathrm{~kg}$ per pig for the HP-groups and $1.56 \mathrm{~kg}$ per pig for the LP-groups. Gaseous emissions in the room with LP-groups were, compared with the emissions in the room with HP-groups, $26.1 \%$ lower for $\mathrm{NH}_{3}$ (10.60 vs. $14.35 \mathrm{~g}$ per pig per day), $12.8 \%$ lower for $\mathrm{CH}_{4}$ (13.12 vs. 15.04 g per pig per day) and 2 times higher for $\mathrm{N}_{2} \mathrm{O}$ ( $1.02 \mathrm{vs.} 0.52 \mathrm{~g}$ per pig per day). The emissions of $\mathrm{CO}_{2}$ and $\mathrm{H}_{2} \mathrm{O}$ were not significantly different according to the diet $\mathrm{CP}$ level.
\end{abstract}

fattening pig / crude protein / ammonia / nitrous oxide / methane

Résumé - Effets d'une réduction de la teneur en protéine brute de l'aliment sur les émissions de gaz associées à l'élevage de porcs charcutiers sur litières accumulées. Deux lots successifs de 32 porcs charcutiers par lot ont été chacun subdivisés en 2 groupes de 16 nourris soit avec un aliment à haute teneur en protéine brute (groupes HP) ou un aliment à faible teneur en protéine brute complémenté avec des acides aminés synthétiques (groupes FP). Les porcs ont été hébergés sur des litières accumulées de paille, dans des locaux distincts en fonction de l'aliment reçu. Une fois par mois, les émissions d'ammoniac $\left(\mathrm{NH}_{3}\right)$, de protoxyde d'azote $\left(\mathrm{N}_{2} \mathrm{O}\right)$, de méthane $\left(\mathrm{CH}_{4}\right)$, de dioxyde de carbone $\left(\mathrm{CO}_{2}\right)$ et de vapeur d'eau $\left(\mathrm{H}_{2} \mathrm{O}\right)$ ont été mesurées en continu durant 6 jours consécutifs.

\footnotetext{
* Corresponding author: Baudouin.Nicks@ulg.ac.be
} 
Les consommations moyennes d'azote $(\mathrm{N})$ des porcs des groupes HP et FP ont été respectivement de $6,83 \mathrm{~kg}$ et $5,78 \mathrm{~kg}$ par animal, pour des poids moyens des porcs en début et fin d'engraissement de 26,6 et $111,4 \mathrm{~kg}$. Les gains moyens quotidiens n'ont pas été significativement différents en fonction de la teneur en protéine brute des aliments. A la fin des périodes d'engraissement, les contenus en azote des litières accumulées des groupes HP et FP ont été respectivement de 1,84 $\mathrm{kg}$ et 1,56 kg par porc. Les émissions de gaz au sein du local hébergeant les groupes FP ont été, comparées à celles relevées dans le local hébergeant les groupes $\mathrm{HP}$, inférieures de $26,1 \%$ pour $\mathrm{NH}_{3}(10,60$ vs. $14,35 \mathrm{~g}$ par porc par jour), inférieures de $12,8 \%$ pour $\mathrm{CH}_{4}$ (13,12 vs. 15,04 g par porc par jour) et 2 fois plus élevées pour $\mathrm{N}_{2} \mathrm{O}$ (1,02 vs. 0,52 g par porc par jour). Les émissions de $\mathrm{CO}_{2}$ et d' $\mathrm{H}_{2} \mathrm{O}$ n'ont pas été significativement différentes en fonction de la teneur en protéine brute des aliments.

porc charcutier / protéine brute / ammoniac / protoxyde d'azote / méthane

\section{INTRODUCTION}

Livestock productions contribute to pollutant gaseous emissions $[3,5]$. There are ammonia $\left(\mathrm{NH}_{3}\right)$ emissions that contribute to soil and water acidifications $[6,18,19$, 22]. In addition, ammonia is well known as a toxic gas irritating the respiratory tract [19] at concentrations exceeding 15 p.p.m. There are also emissions of greenhouse gases like carbon dioxide $\left(\mathrm{CO}_{2}\right)$, methane $\left(\mathrm{CH}_{4}\right)$ and nitrous oxide $\left(\mathrm{N}_{2} \mathrm{O}\right)[5,13,18]$. These three gases do not have the same warming potential, which is for $\mathrm{CH}_{4}$ and $\mathrm{N}_{2} \mathrm{O}$ respectively 23 and 296 times that of $\mathrm{CO}_{2}$ [9]. $\mathrm{N}_{2} \mathrm{O}$ also contributes to the destruction of ozone. In France, it is estimated that $80 \%$ of $\mathrm{NH}_{3}$-emissions, $76 \%$ of $\mathrm{N}_{2} \mathrm{O}$-emissions, $70 \%$ of $\mathrm{CH}_{4}$-emissions and $14 \%$ of $\mathrm{CO}_{2}$-emissions come from agriculture [3]. For $\mathrm{CO}_{2}$ however, agriculture is also a consumer via plant photosynthesis.

The principal source of ammonia results from the degradation of urea by urease, an enzyme produced by micro-organisms that are commonly present in manure. $\mathrm{N}_{2} \mathrm{O}$ is produced during nitrification - denitrification reactions in manure when optimal conditions are not met for a complete $\mathrm{N}$ reduction to $\mathrm{N}_{2}$. The transformation of organic material in manure is also accompanied by the release of carbon in the form of $\mathrm{CO}_{2}$ and $\mathrm{CH}_{4}$. These two gases also originate respectively from the respiratory tract and the enteric tract of pigs [13].
Many factors can influence $\mathrm{NH}_{3}$ emissions. Among these, the $\mathrm{N}$ content of the manure is one of the more important. It is principally a function of diet crude protein $(\mathrm{CP})$ content and animal capacity to use it. It has already been shown that lowering the $\mathrm{CP}$ content of diets balanced with industrial amino acids (AA) to maintain performance, decreased the manure $\mathrm{N}$-content and in consequence the $\mathrm{NH}_{3}$-emissions. Canh et al. [2] obtained a $30 \%$ reduction of manure-N (7.65 versus $11.13 \mathrm{~g} \mathrm{~N} \cdot 100 \mathrm{~g}^{-1}$ dry matter) and a $50 \%$ reduction of $\mathrm{NH}_{3}$-emissions (4.79 versus $9.44 \mathrm{~g}$ per pig per day) by lowering CP content from 16.5 to $12.5 \%$ with pigs reared on partially slatted floor. Experiments conducted by Hayes et al. [8] on partially slatted floor showed $60 \%$ reduction of $\mathrm{NH}_{3}$-emissions (3.11 versus 8.27 g per pig per day) by lowering the $\mathrm{CP}$ content from 20.9 to $13.2 \%$. In metabolic cages, with diets containing $20 \%$ and $12 \%$ CP, Portejoie et al. [20] obtained 56\% reduction of manure $\mathrm{N}$-content and $76 \%$ reduction of $\mathrm{NH}_{3}$-emissions. In all these experiments, essential AA levels were balanced to meet pig requirement and performances were maintained between animals fed with different $\mathrm{N}$-content diet.

Almost all of the research on this topic was done in fattening units with pigs kept on slatted floors and manure handled in the form of slurry. Furthermore, the potential effects of lowering the $\mathrm{CP}$ content of the diet on other gaseous emissions, 
especially $\mathrm{N}_{2} \mathrm{O}$, were not studied simultaneously. The aims of this research were to study the effect of a $\mathrm{CP}$ reduction of the diet on manure-N content and on gaseous emissions when fattening pigs were kept on deep litter.

\section{MATERIALS AND METHODS}

\subsection{Animals}

Two successive batches of 32 Belgian Landrace-type pigs per batch were each divided into 2 homogenous groups of 16 pigs according to sex and weight, the HPgroups fed a high CP level diet and the LPgroups fed a low CP level diet.

During the fattening of the second batch in the HP-group, one loss occurred after 1 week and one loss 16 days before the end of the experiment but after the last series of gaseous emissions measurements. After the first loss, a same-weight pig was added to the group with the objective to keep the same floor area per pig in the $2 \mathrm{ex}$ perimental rooms. However, since this pig never grew like the others its performance was not taken into account to calculate the mean daily weight gain of the group.

\subsection{Experimental rooms}

Pigs were housed in two identical rooms, one for the HP-groups and another one for the LP-groups. The rooms had a $30 \mathrm{~m}^{2}$ horizontal area and a volume of $103 \mathrm{~m}^{3}$. They were arranged to keep pigs in a pen on a straw deep litter with an available floor space of $1.35 \mathrm{~m}^{2}$ per animal. The same amount of straw was used for each batch and each group, i.e. about $47 \mathrm{~kg}$ of straw per pig. Ventilation was provided using an exhaust fan in each room and the ventilation rates were adapted automatically to maintain a constant ambient temperature. The air inlet was an opening of $0.34 \mathrm{~m}^{2}$ connected to a service corridor of the building.

\subsection{Feeding}

Pigs were fed ad libitum either a high $\mathrm{CP}$ level diet (HP-diet) or a low CP level diet (LP-diet). Each group received a grower meal for about 40 days, followed by a finishing meal. Table I shows composition and characteristics of each of the four meals. The grower and the finishing meals fed to the HP-groups contained respectively $18.1 \%$ and $17.5 \% \mathrm{CP}$ and the two meals fed to the LP-groups $15.5 \%$ and $14.0 \% \mathrm{CP}$. The four diets contained 10000 I.U. vitamin A, 2000 I.U. vitamin $\mathrm{D}_{3}$ and $80 \mathrm{mg}$ vitamin $\mathrm{E}$ per $\mathrm{kg}$. Meals were supplemented and balanced with AA to meet pig requirements in agreement with the recommendations of the National Research Council (NRC), both for the growing period (body weight $20-50 \mathrm{~kg}$ ) and the finishing period (body weight 50 $120 \mathrm{~kg}$ ). Requirements were assumed both in terms of $\%$ of essential AA in the diets and on the ratios of other essential AA to lysine [12]. Table I shows that the essential AA contents of the HP-diet and LP-diet were very similar.

The feeding equipment was composed of two single-spaced feeders per pen with an integrated watering nipple. Meters (Wateau ${ }^{\circledR}$, EEC approval No. B02 314.29) were used to determine the water consumption per pen. Feed and water intakes and feed conversion ratio were determined per group.

\subsection{Measurement of gas emissions}

The gas concentrations in the air of the experimental rooms and of the corridor providing fresh air were measured with a 1312 Photoacoustic Multi-gas Monitor (Innova Air Tech Instruments) equipped to measure $\mathrm{NH}_{3}, \mathrm{~N}_{2} \mathrm{O}, \mathrm{CH}_{4}, \mathrm{CO}_{2}$ and $\mathrm{H}_{2} \mathrm{O}$. During the raising of each batch, four measurement series of six consecutive days were conducted with a 1-month interval 
Table I. Content and characteristics of the high crude protein level diets ('HP-diet') and the low crude protein level diets ('LP-diet').

\begin{tabular}{|c|c|c|c|c|}
\hline & \multicolumn{2}{|c|}{ HP-diet } & \multicolumn{2}{|c|}{ LP-diet } \\
\hline & $\begin{array}{c}\text { Grower } \\
\text { meal }\end{array}$ & $\begin{array}{c}\text { Finishing } \\
\text { meal }\end{array}$ & $\begin{array}{c}\text { Grower } \\
\text { meal }\end{array}$ & $\begin{array}{c}\text { Finishing } \\
\text { meal }\end{array}$ \\
\hline \multicolumn{5}{|l|}{ Composition (\%) } \\
\hline Humidity & 12.5 & 11.9 & 12.2 & 12.3 \\
\hline Crude protein & 18.1 & 17.5 & 15.5 & 14.0 \\
\hline Ether extract & 4.7 & 3.8 & 4.1 & 2.8 \\
\hline Ash & 5.3 & 4.7 & 5.2 & 4.1 \\
\hline Crude cellulose & 5.0 & 6.0 & 4.8 & 5.2 \\
\hline \multicolumn{5}{|l|}{ Minerals } \\
\hline Calcium & 0.73 & 0.57 & 0.90 & 0.56 \\
\hline Phosphorus & 0.45 & 0.37 & 0.44 & 0.34 \\
\hline \multicolumn{5}{|l|}{ Digestible amino acids } \\
\hline Lysine & 0.85 & 0.74 & 0.85 & 0.75 \\
\hline Methionine & 0.27 & 0.23 & 0.28 & 0.25 \\
\hline Cystine & 0.24 & 0.23 & 0.22 & 0.20 \\
\hline Tryptophan & 0.17 & 0.16 & 0.15 & 0.13 \\
\hline Threonine & 0.50 & 0.46 & 0.49 & 0.47 \\
\hline \multicolumn{5}{|l|}{ Raw materials (\%) } \\
\hline Cereals & 62.2 & 66.5 & 77.1 & 81.1 \\
\hline Soybean meal & 24.8 & 21.3 & 17.5 & 9.4 \\
\hline Palmist schilfers & l & 4.0 & / & 2.5 \\
\hline Other components & 12.9 & 8.1 & 4.9 & 6.4 \\
\hline \multicolumn{5}{|l|}{ Supplemented amino acids } \\
\hline L-Lysine HCL & 0.11 & 0.07 & 0.37 & 0.40 \\
\hline L-Threonine & / & l & 0.09 & 0.15 \\
\hline DL-Methionine & 0.06 & 0.02 & 0.09 & 0.08 \\
\hline L-Tryptophan & I & 1 & 0.01 & 0.01 \\
\hline Net energy $\left(\mathrm{kcal} \cdot \mathrm{kg}^{-1}\right)$ & 2230 & 2190 & 2230 & 2190 \\
\hline
\end{tabular}

between the series. The first series began 3 weeks after the arrival of the pigs. The sampling of the air in the rooms was performed above the exhaust fan, and that of the air of the corridor at about $1 \mathrm{~m}$ from the air inlets. The air was analysed every hour.

The ventilation rates were continuously measured by an electronic device (Exavent, Fancom ${ }^{\circledR}$ ) and the hourly means were recorded.

Emissions (E), expressed as $\mathrm{mg} \cdot \mathrm{h}^{-1}$ were calculated according to the following formula:

$$
\mathrm{E}=\mathrm{D} \times\left(\mathrm{C}_{\mathrm{i}}-\mathrm{C}_{\mathrm{e}}\right),
$$

with $\mathrm{D}$, the hourly mass flow (kg air per h); $\mathrm{C}_{\mathrm{i}}$ and $\mathrm{C}_{\mathrm{e}}$, respectively the concentrations of gas in the air of the room and corridor (mg. $\mathrm{kg}^{-1}$ dry air).

Hourly data were used for the statistical analyses.

The cumulative emission of nitrogen $\left(\mathrm{N}_{\mathrm{c}}\right)$ in the form of $\mathrm{NH}_{3}$ and $\mathrm{N}_{2} \mathrm{O}$ was determined using the relation:

$$
\begin{aligned}
\mathrm{N}_{\mathrm{c}}=(14 / 17) \times & \mathrm{NH}_{3} \text {-emission } \\
& +(28 / 44) \times \mathrm{N}_{2} \mathrm{O} \text {-emission. }
\end{aligned}
$$


$\mathrm{N}_{2}$ - $\mathrm{N}$ emissions from deep litters were estimated as:

$$
\begin{aligned}
& \mathrm{N}_{2}-\mathrm{N}=(\text { litter- } \mathrm{N}+\text { feed- }) \\
& \quad-\left(\text { retained-N }+ \text { deep litter- } \mathrm{N}+\mathrm{N}_{\mathrm{c}}-\mathrm{N}\right) .
\end{aligned}
$$

The $\mathrm{N}$ retained in animal products $\left(\mathrm{N}_{\mathrm{r}}\right)$ was estimated by the following equation established by CORPEN [4]:

$$
\begin{aligned}
& \mathrm{N}_{\mathrm{r}}(\text { kg per pig })=\mathrm{e}^{(-0.9385-0.0145 \times \mathrm{LY})} \\
& \quad \times\left(0.915 \mathrm{WG}^{1.009}\right)^{(0.7364+0.0044 \times \mathrm{LY})} / 6.25,
\end{aligned}
$$

LY is the lean yield of carcass (\%) and WG the weight gain $(\mathrm{kg})$.

The deep-litter nitrogen content was calculated knowing the amount of deep litter produced and its nitrogen content determined by the Kjeldahl method.

\subsection{Statistical analyses}

For each batch and each gas, the differences of the emissions with regards to the diet CP level (HP-diet or LP-diet) were tested in the form of a mixed model for repeated measurements with two criteria $\left(\mathrm{SAS}^{\circledR}\right.$ software, proc MIXED) [21]: diet CP content (1 d.f.), period of measurements ( 3 d.f.) and interaction between diet CP content and period of measurement, four replicates per diet (periods) and 144 ( $24 \mathrm{~h} \times 6$ days) successive measurements per replicate. Residuals were assumed normally distributed, with a null expectation. Correlation between successive measurements was modelled using a type 1-autoregressive structure.

The combined data obtained with the two batches were treated in the same way as for the previous analyses.

\section{RESUTS}

\subsection{Climatic characteristics of the rooms}

The mean air temperatures were $21.2{ }^{\circ} \mathrm{C}$ (s.d. 0.29) in the room with the HP-groups, $21.8^{\circ} \mathrm{C}$ (s.d. 0.39) in the room with the LP-groups and $17.9{ }^{\circ} \mathrm{C}$ (s.d. 0.99) in the corridor providing fresh air (s.d. between batches). The mean ventilation rates were 1319 (s.d. 265) and $1529 \mathrm{~m}^{3} \cdot \mathrm{h}^{-1}$ (s.d. 245) for the two rooms respectively (s.d. between batches).

\subsection{Performance of the animals}

The average initial body-weights for the HP-group and the LP-group were respectively $24.7 \pm 3.2 \mathrm{~kg}$ and $24.6 \pm 3.5 \mathrm{~kg}$ for the first batch and $28.4 \pm 4.0$ and $28.8 \pm 4.2 \mathrm{~kg}$ for the second batch. Pigs fed the HP-diet eat on average $63.3 \mathrm{~kg}$ per pig of the grower meal $(18.1 \% \mathrm{CP})$ and $178.9 \mathrm{~kg}$ per pig of the finishing meal $(17.5 \% \mathrm{CP})$ and pigs fed the LP-diet eat $63.3 \mathrm{~kg}$ per pig $(15.5 \% \mathrm{CP})$ and $188.3 \mathrm{~kg}$ per pig $(14.0 \% \mathrm{CP})$ of the two meals respectively. The mean CP contents of the diets fed to the two groups were $17.64 \%$ and $14.37 \%$ and the mean $\mathrm{N}$ intakes of the HP-groups and the LP-groups were thus $6.83 \mathrm{~kg}$ and $5.78 \mathrm{~kg}$ per pig respectively, i.e. a difference of $15.4 \%$.

Table II shows the performance of the animals. Feed conversion ratios were corrected with coefficients of standardization for fattening pigs from 30 to $115 \mathrm{~kg}$ [1]. There was no significant difference between the daily weight gains of the pigs fed the HP-diet and those fed the LP-diet.

\subsection{Characteristics of the deep litters}

Table III shows the compositions of the deep litters for the two batches at the end 
Table II. Performance of the pigs (mean \pm s.d.) fed with a high crude protein level diet ('HP-group') or a low crude protein level diet ('LP-group').

\begin{tabular}{lcccc}
\hline & \multicolumn{2}{c}{ Batch 1 } & \multicolumn{2}{c}{ Batch 2 } \\
\cline { 2 - 5 } & HP-group & LP-group & HP-group & LP-group \\
\hline Number of pigs & 16 & 16 & 16 & 16 \\
Initial weight $(\mathrm{kg})$ & $24.7 \pm 3.2$ & $24.6 \pm 3.5$ & $28.4 \pm 4.0$ & $28.8 \pm 4.2$ \\
Final weight $(\mathrm{kg})$ & $106.3 \pm 10.3$ & $108.3 \pm 10.9$ & $111.9 \pm 12.9$ & $118.9 \pm 10.8$ \\
Lean yield $(\%)$ & $59.8 \pm 5.0$ & $58.3 \pm 2.7$ & $60.2 \pm 5.2$ & $59.1 \pm 3.0$ \\
Losses (number) & 0 & 0 & 2 & 0 \\
Duration (days) & 118 & 118 & 118 & 118 \\
Daily weight gain $(\mathrm{g})$ & $692 \pm 84$ & $710 \pm 88$ & $708 \pm 89$ & $764 \pm 74$ \\
Daily feed intake $(\mathrm{kg}$ & 2.0 & 2.1 & 2.2 & 2.2 \\
per day) & & & & \\
Feed conversion ratio & 2.93 & 2.95 & 3.10 & 2.92 \\
(kg/kg) & 3.07 & 3.07 & 3.14 & 2.9 \\
Feed conversion ratio & & & & \\
standardized $(\mathrm{kg} / \mathrm{kg}) *$ & $0.91 \pm 0.10$ & $0.87 \pm 0.15$ & $1.14 \pm 0.12$ & $1.15 \pm 0.08$ \\
Price (€ per kg BW) & & & & \\
Water drunk (L) & 4.26 & 4.26 & 4.51 & 4.44 \\
$\quad$ Per pig per day & 2.10 & 2.04 & 2.15 & 2.05 \\
$\quad$ Per kg of food & & & & \\
\hline
\end{tabular}

* According to the coefficients of standardization established by Aubry et al. [1] for fattening pigs from 30 to $115 \mathrm{~kg}$.

Table III. Composition of straw deep litters at the end of the fattening of each batch of pigs fed with a high crude protein level diet ('HP-group') or a low crude protein level diet ('LP-group').

\begin{tabular}{|c|c|c|c|c|c|c|c|c|}
\hline & $\begin{array}{c}\text { Amount } \\
\text { removed } \\
\text { (kg per } \\
\text { pig) }\end{array}$ & $\begin{array}{c}\mathrm{DM} \\
\left(\mathrm{g} \cdot \mathrm{kg}^{-1}\right)\end{array}$ & $\mathrm{pH}$ & $\mathrm{C} / \mathrm{N}$ & $\begin{array}{c}\text { Kjeldahl-N } \\
\left(\mathrm{g} \cdot \mathrm{kg}^{-1} \mathrm{DM}\right)\end{array}$ & $\begin{array}{c}\mathrm{NH}_{4}^{+}-\mathrm{N} \\
\left(\mathrm{g} \cdot \mathrm{kg}^{-1} \mathrm{~N}\right)\end{array}$ & $\begin{array}{c}\mathrm{K}_{2} \mathrm{O} \\
\left(\mathrm{g} \cdot \mathrm{kg}^{-1} \mathrm{DM}\right)\end{array}$ & $\begin{array}{c}\mathrm{P}_{2} \mathrm{O}_{5} \\
\left(\mathrm{~g} \cdot \mathrm{kg}^{-1} \mathrm{DM}\right)\end{array}$ \\
\hline HP-group & 205 & 340 & 8.12 & 15.94 & 30.0 & 366 & 34.1 & 9.2 \\
\hline Batch 1 LP-group & 146 & 360 & 8.51 & 14.08 & 34.1 & 245 & 30.6 & 13.5 \\
\hline HP-group & 165 & 287 & 8.78 & 14.05 & 33.0 & 302 & 35.6 & 10.1 \\
\hline $\begin{array}{l}\text { Batch } 2 \text { LP-group } \\
\end{array}$ & 153 & 383 & 8.26 & 20.74 & 22.3 & 176 & 32.8 & 13.2 \\
\hline
\end{tabular}

DM: dry matter; $\mathrm{C} / \mathrm{N}$ : carbon-nitrogen ratio.

of the fattening periods. The amounts of straw manure produced by the HP-groups and the LP-groups were respectively 185 and $149 \mathrm{~kg}$ per pig. The N-contents of the litters were $1.83 \mathrm{~kg}$ per pig for the HPgroups and $1.55 \mathrm{~kg}$ per pig for the LPgroups with a $\mathrm{NH}_{4}{ }^{+}-\mathrm{N}$ content of 334 and $210 \mathrm{~g} \cdot \mathrm{kg}^{-1} \mathrm{~N}$, respectively.

\subsection{Gas emissions}

The mean gas emissions for each batch are presented in Table IV. Figure 1 shows the evolution of the emissions from the beginning to the end of each fattening period. Over the 2 fattening periods altogether, gaseous emissions in the room where pigs 
Table IV. Gas emissions (per pig and per day) during the raising of two batches of fattening pigs on a straw deep litter and fed with a high crude protein level diet ('HP-group') or a low crude protein level diet ('LP-group').

\begin{tabular}{cccccc}
\hline & & HP-group & LP-group & \multicolumn{1}{c}{ s.e. } & Significance \\
\hline \multirow{5}{*}{ Batch 1 } & $\mathrm{NH}_{3}(\mathrm{~g})$ & 17.14 & 13.46 & 0.823 & $*$ \\
& $\mathrm{~N}_{2} \mathrm{O}(\mathrm{g})$ & 0.41 & 0.58 & 0.010 & $* *$ \\
& $\mathrm{~N}_{\mathrm{c}}(\mathrm{g})$ & 14.37 & 11.45 & 0.679 & $\mathrm{NS}$ \\
& $\mathrm{CH}_{4}(\mathrm{~g})$ & 13.94 & 10.93 & 0.253 & $* *$ \\
& $\mathrm{CO}_{2}(\mathrm{~kg})$ & 1.98 & 2.16 & 0.036 & $*$ \\
& $\mathrm{H}_{2} \mathrm{O}(\mathrm{kg})$ & 3.67 & 3.83 & 0.098 & $\mathrm{NS}$ \\
\hline \multirow{5}{*}{ Batch 2 } & $\mathrm{NH}_{3}(\mathrm{~g})$ & 11.56 & 7.74 & 0.585 & $*$ \\
& $\mathrm{~N}_{2} \mathrm{O}(\mathrm{g})$ & 0.63 & 1.45 & 0.153 & $*$ \\
& $\mathrm{~N}_{\mathrm{c}}(\mathrm{g})$ & 9.91 & 7.30 & 0.487 & $*$ \\
& $\mathrm{CH}_{4}(\mathrm{~g})$ & 16.14 & 15.32 & 0.209 & $\mathrm{NS}$ \\
& $\mathrm{CO}_{2}(\mathrm{~kg})$ & 1.85 & 1.80 & 0.029 & $\mathrm{NS}$ \\
& $\mathrm{H}_{2} \mathrm{O}(\mathrm{kg})$ & 3.19 & 2.93 & 0.077 & $\mathrm{NS}$ \\
\hline \multirow{5}{*}{ Batches 1 and 2 2} & $\mathrm{NH}_{3}(\mathrm{~g})$ & 14.35 & 10.60 & 0.650 & $* *$ \\
& $\mathrm{~N}_{2} \mathrm{O}(\mathrm{g})$ & 0.52 & 1.02 & 0.113 & $*$ \\
& $\mathrm{~N}_{\mathrm{c}}(\mathrm{g})$ & 12.14 & 9.37 & 0.520 & $* *$ \\
& $\mathrm{CH}_{4}(\mathrm{~g})$ & 15.04 & 13.12 & 0.210 & $* * *$ \\
& $\mathrm{CO}_{2}(\mathrm{~kg})$ & 1.92 & 1.98 & 0.029 & $\mathrm{NS}$ \\
& $\mathrm{H}_{2} \mathrm{O}(\mathrm{kg})$ & 3.43 & 3.38 & 0.080 & $\mathrm{NS}$ \\
\hline
\end{tabular}

s.e.: Standard error of least squares means; significance: NS: $P>0.05$; *: $P<0.05$; **: $P<0.01$; ***: $P<0.001 ; \mathrm{N}_{\mathrm{c}}$ : cumulative emissions of nitrogen in the form of ammonia and nitrous oxide $\left(\mathrm{NH}_{3}-\mathrm{N}+\right.$ $\left.\mathrm{N}_{2} \mathrm{O}-\mathrm{N}\right)$.

were fed the LP-diet, compared to pigs fed the HP-diet, were $26.1 \%$ lower for $\mathrm{NH}_{3}$ $(P<0.01), 12.8 \%$ lower for $\mathrm{CH}_{4}(P<$ $0.001)$ and 2.0 times higher for $\mathrm{N}_{2} \mathrm{O}(P<$ 0.05). The emissions of $\mathrm{CO}_{2}$ and $\mathrm{H}_{2} \mathrm{O}$ were not significantly different according to the diet $\mathrm{CP}$ level. Whatever the diet and the batch, $\mathrm{NH}_{3}, \mathrm{CH}_{4}, \mathrm{CO}_{2}$ and $\mathrm{H}_{2} \mathrm{O}$ emissions increased regularly during the fattening periods. On average, the $\mathrm{NH}_{3}$ emissions were 4.2 times higher at the end compared with the beginning, those of methane, 4.7 times, those of $\mathrm{CO}_{2}$ and $\mathrm{H}_{2} \mathrm{O}, 2.3$ times.

\subsection{Nitrogen balance}

Over the two fattening periods altogether, the feed-N supply was $6.83 \mathrm{~kg}$ per pig with the HP-diet and $5.78 \mathrm{~kg}$ per pig with the LP-diet. From these quantities, the proportions retained by the pigs were respectively $30.2 \%(2.06 \mathrm{~kg})$ with the HPdiet and $37.4 \%(2.16 \mathrm{~kg})$ with the LP-diet. So, the amounts of feed-N excreted were 4.77 and $3.62 \mathrm{~kg}$ per pig respectively.

Table $\mathrm{V}$ presents the nitrogen excreted by pigs (wastes-N). The manure-N represents the quantity of nitrogen in the litter apart from the straw-N supply, which was of $0.29 \mathrm{~kg}$ per pig. The manure $\mathrm{N}$-content of the deep litter was on average $1.54 \mathrm{~kg}$ per pig when they were fed the HP-diet and $1.26 \mathrm{~kg}$ per pig with the LP-diet. However, the ratios manure-N/feed-N were similar with the two diets (22.6 and $21.9 \%$ ). Whatever the diet, about $66 \%$ of the $\mathrm{N}$ excreted by the pigs was recovered in the gas form with $29 \%$ in the form of $\mathrm{NH}_{3}, 1 \%$ of $\mathrm{N}_{2} \mathrm{O}$ and $36 \%$ in the form of $\mathrm{N}_{2}$. 
a)

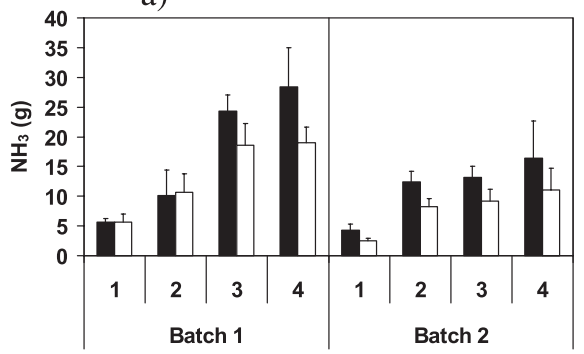

b)

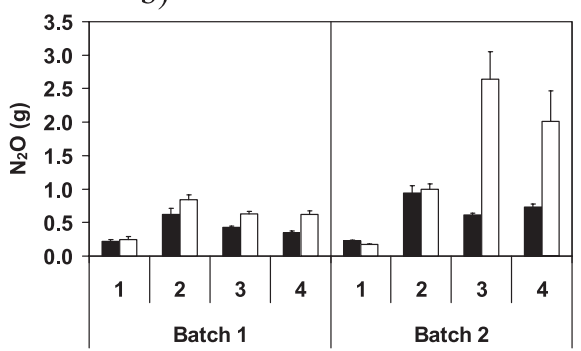

c)

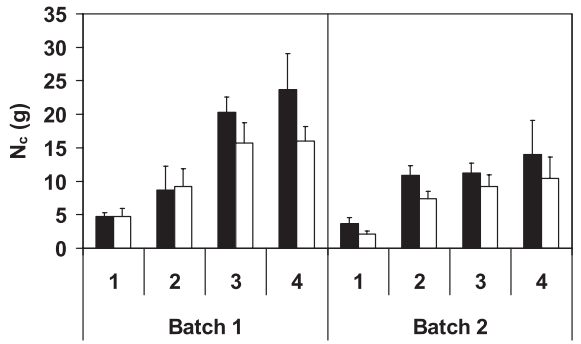

d)

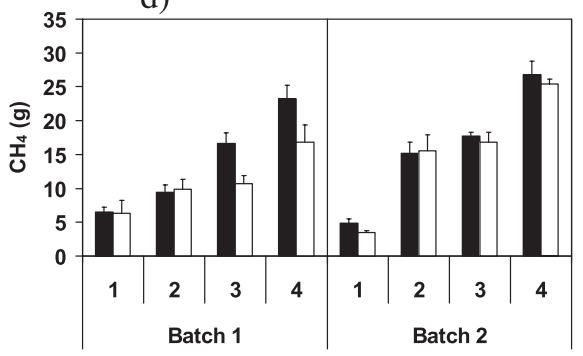

e)

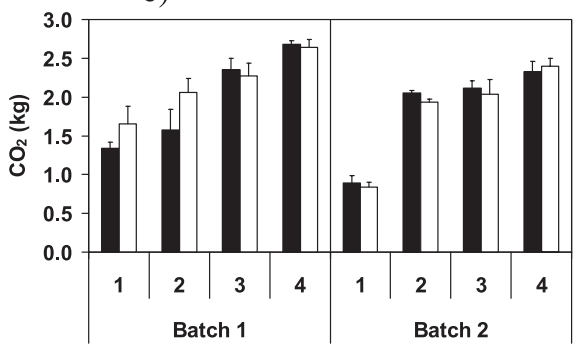

f)

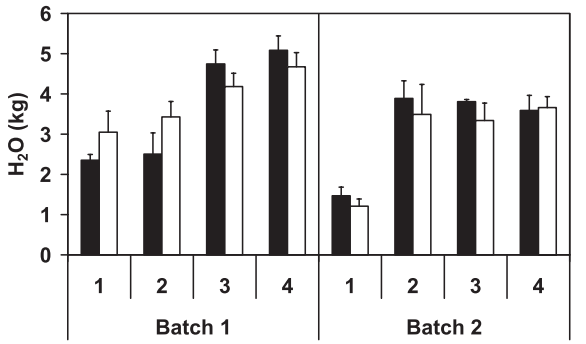

Figure 1. Evolution of gas emissions of ammonia (a), nitrous oxide (b), cumulative nitrogen ( $\mathrm{Nc}$ ) in the form of ammonia and nitrous oxide (c), methane (d), carbon dioxide (e) and water vapor (f), expressed per pig and per day, for four series of measurements (mean \pm s.d.), at one month interval, with 6 days of measurements per series during the raising of two batches of fattening pigs on straw deep litter and fed with a high crude protein level diet (closed bars) or a low crude protein level diet (open bars).

\section{DISCUSSION}

The mean daily weight gain of pigs was no significantly different between the HP-diet and the AA supplemented LP-diet. This was in agreement with several authors when comparing diets with high or low protein contents but balanced in essential AA $[2,8,10,11,16,20,24-26]$.

The estimated nitrogen $\left(\mathrm{N}_{\mathrm{r}}\right)$ was $23.6 \%$ higher for the LP-groups compared with the HP-groups ( $37.4 \%$ versus $30.2 \%$ ), expressed in percentage of feed-N. While the mean CP content of the two diets were $17.64 \%$ and $14.37 \%$, the $\mathrm{N}_{\mathrm{r}}$ increased 
Table V. N excreted by pigs (wastes-N) during the fattening period for each batch, with regards to diet fed ('HP-group' for pigs fed with a high crude protein level diet and 'LP-group' for the pigs fed with a low crude protein level diet), expressed in $\mathrm{kg}$ per pig and in percentage of wastes-N.

\begin{tabular}{lcccccccc}
\hline & \multicolumn{4}{c}{ Batch 1 } & \multicolumn{4}{c}{ Batch 2 } \\
\cline { 2 - 9 } & \multicolumn{2}{c}{ kg per pig } & \% of wastes-N & \multicolumn{2}{c}{ kg per pig } & \% of wastes-N \\
\cline { 2 - 9 } & $\begin{array}{c}\text { HP- } \\
\text { group }\end{array}$ & $\begin{array}{c}\text { LP- } \\
\text { group }\end{array}$ & $\begin{array}{c}\text { HP- } \\
\text { group }\end{array}$ & $\begin{array}{c}\text { LP- } \\
\text { group }\end{array}$ & $\begin{array}{c}\text { HP- } \\
\text { group }\end{array}$ & $\begin{array}{c}\text { LP- } \\
\text { group }\end{array}$ & $\begin{array}{c}\text { HP- } \\
\text { group }\end{array}$ & $\begin{array}{c}\text { LP- } \\
\text { group }\end{array}$ \\
\hline Manure-N & 1.81 & 1.51 & 38.4 & 42.0 & 1.28 & 1.01 & 26.5 & 27.8 \\
$\mathrm{NH}_{3}-\mathrm{N}$ & 1.67 & 1.31 & 35.4 & 36.3 & 1.17 & 0.78 & 24.3 & 21.5 \\
$\mathrm{~N}_{2} \mathrm{O}-\mathrm{N}$ & 0.03 & 0.04 & 0.6 & 1.2 & 0.05 & 0.11 & 1.0 & 3.1 \\
$\mathrm{~N}_{2}-\mathrm{N}$ & 1.21 & 0.74 & 25.6 & 20.5 & 2.33 & 1.73 & 48.2 & 47.7 \\
Total excreted-N & 4.71 & 3.60 & 100 & 100 & 4.83 & 3.64 & 100 & 100 \\
\hline
\end{tabular}

of $+7.2 \%$ for each percentage reduction of diet CP level. Such an improvement has been observed by several authors with values between $+1.7 \%$ and $+5.8 \%$ for each percentage reduction of diet CP level [2, 16, 20, 25, 26]. However, Otto et al. [17] mentioned that reducing dietary $\mathrm{CP}$ below a certain concentration may impair gut functions and as such affect whole body $\mathrm{N}$ retention.

As expected, the total nitrogen excreted per pig was $24.1 \%$ lower with the LPdiet compared with the HP-diet. This Nexcreted decrease amounted to $7.4 \%$ per each percentage reduction of diet $\mathrm{CP}$ content. This is on a scale of results from other authors $[2,16,17,20,25,26]$ according to whom N-excreted decreased by about $8 \%$ per each percentage reduction of diet $\mathrm{CP}$ content.

The N-contents of manure were, on average for two batches, $1.54 \mathrm{~kg}$ per pig with the HP-diet and $1.26 \mathrm{~kg}$ with the LP-diet. Both values were in accordance with results from a previous experiment $(1.47 \mathrm{~kg}$ per pig) [14] and confirm that the $\mathrm{N}$ content of deep litter is much lower than the $\mathrm{N}$ content of slurry which is about 2.7 to $3.25 \mathrm{~kg}$ per pig [4].

The $\mathrm{NH}_{3}$-emissions related to the HPdiet, on average $14.4 \mathrm{~g}$ per pig per day or $29.8 \%$ of wastes-N, were in agreement with a previous experiment with the same housing conditions and a similar diet, i.e. $13.61 \mathrm{~g}$ per pig per day or $27.6 \%$ of wastes$\mathrm{N}$ [14]. Feeding the LP-diet allowed to reduce the emissions of $3.75 \mathrm{~g}$ per pig per day, i.e. of $26.1 \%$ or around $8 \%$ per each percentage reduction of diet $\mathrm{CP}$ content. Studies about $\mathrm{NH}_{3}$-emissions from slurry showed reductions varying from 8.1 to $13.3 \%$ per diet CP percentage unit decrease $[2,8,17,20]$.

The nitrous oxide emissions were on average 0.52 and $1.02 \mathrm{~g}$ per pig per day for the HP-groups and the LP-groups respectively, representing $0.8 \%$ and $2.1 \%$ of total $\mathrm{N}$-excreted. $\mathrm{N}_{2} \mathrm{O}$ emissions from deep litters are very variable. Hassouna et al. [7] estimated between 4 and $12 \%$ the $\mathrm{N}_{2} \mathrm{O}$ emissions from straw-based deep litters with less than $2 \mathrm{~m}^{2}$ floor space per pig. But a negligible value $(0.15 \%)$ was observed by Nicks et al. [14]. Obviously other factors than the $\mathrm{CP}$ content of the diets are more important in regards with $\mathrm{N}_{2} \mathrm{O}$ emissions, like the oxygenation level of the litter and the surface of the dunging area.

The total gaseous nitrogen emissions represented $68 \%$ and $65 \%$ of the total $\mathrm{N}$ excreted with the 'HP-group' and the 'LP-group' respectively. These high levels, compared with $\mathrm{N}$-emissions from slurry estimated at $25 \%$ [4], were in agreement with other data $[4,14]$ and are in relation with the $\mathrm{N}_{2}$-emissions from deep-litters. 
$\mathrm{CH}_{4}$-emissions were 15.04 and $13.12 \mathrm{~g}$ per pig per day with the 'HPgroup' and 'LP-group', respectively. In an experiment with the fattening of three successive batches on deep litter without changing the litter between batches, the mean $\mathrm{CH}_{4}$-emissions observed during the stay of the three batches were respectively $3.25,6.25$ and $12.67 \mathrm{~g}$ per pig per day [14]. These data show that the variation observed in regards with the $\mathrm{CP}$ content is small compared with other sources of variation as the oxygenation level of the litter, the temperature of the litter and the surface of the dunging area.

$\mathrm{CO}_{2}$-emissions were not significantly different between the 2 groups with a mean of $1.95 \mathrm{~kg}$ per pig per day. Since the $\mathrm{CO}_{2}$ produced with the respiration of the animals is estimated at about $1.56 \mathrm{~kg}$ per pig per day [23], the contribution of the deep litter to the total emission is relatively low.

Water vapour emissions were not significantly different with regards to the diet $\mathrm{CP}$ content, with an average of $3.4 \mathrm{~kg}$ per pig per day. This production level was higher than that observed when pigs are kept on slatted floors for the high temperatures in the litter, above $30{ }^{\circ} \mathrm{C}$ [15], favouring water evaporation.

In conclusion, when pigs are kept on straw-based deep litter, the decrease of the $\mathrm{CP}$ content of the diet, gives the same advantages as those observed when pigs are kept on slatted floors with manure handled in the form of slurry, i.e. a decrease of the $\mathrm{N}$ content of the manure and of $\mathrm{NH}_{3}$-emissions. Other differences were observed in this study, a decrease in $\mathrm{CH}_{4}$ emissions and an increase in $\mathrm{N}_{2} \mathrm{O}$ emissions but these differences are small compared with those that could be attributed to other factors.

\section{ACKNOWLEDGEMENTS}

This study was supported by the Région wallonne.

\section{REFERENCES}

[1] Aubry A., Quiniou N., Le Cozler Y., Querné M., Modélisation de la croissance et de la consommation d'aliment des porcs de la naissance à l'abattage : actualisation des coefficients appliqués aux critères standardisés de performances en gestion technicoéconomique, $36^{\mathrm{es}}$ Journées de la Recherche Porcine en France, Paris, France, 2004, pp. 409-422.

[2] Canh T.T., Aarnik A.J.A, Schutte J.B., Sutton A., Langhout D.J., Verstegen M.W.A., Dietary protein affects nitrogen excretion and ammonia emissions from slurry of growing-finishing pigs, Livest. Prod. Sci. 56 (1998) 181-191.

[3] Centre Interprofessionnel Technique d'Études de la Pollution Atmosphérique, Inventaire des émissions de polluants atmosphériques en France - Séries sectorielles et analyses étendues, Ministère de l'Écologie et du Développement durable, Paris, 2005.

[4] Comité d'orientation pour des pratiques agricoles respectueuses de l'environnement, Estimation des rejets d'azote, phosphore, potassium, cuivre et zinc des porcs. Influence de la conduite alimentaire et du mode de logement des animaux sur la nature et la gestion des déjections produites, Ministère de l'agriculture, de l'alimentation, de la pêche et des affaires rurales, Ministère de l'écologie et du développement durable, Paris, 2003.

[5] Degré A., Verhève D., Debouche C., Émissions gazeuses en élevage porcin et modes de réduction : revue bibliographique, Biotechnol. Agron. Soc. Environ. 5 (2001) 135-143.

[6] Guingand N., Réduction des émissions d'ammoniac de la convention de Genève à la loi sur l'air, Techni-porc 5 (2002) 19-25.

[7] Hassouna M., Robin P., Texier C., Ramonet Y., $\mathrm{NH}_{3}, \mathrm{~N}_{2} \mathrm{O}, \mathrm{CH}_{4}$ emissions from pigon-litter systems, Proceedings of the International workshop on green pork production, INRA ed., Paris, France, 2005, pp. 121-122.

[8] Hayes E.T., Leek A.B.G., Curran T.P., Dodd V.A., Carton O.T., Beattie V.E., O'Doherty J.V., The influence of diet crude protein level on odour and ammonia emissions from finishing pig house, Bioresource Technol. 91 (2004) 309-315.

[9] IPCC Climate change 2001: The Scientific basis, in: Houghton J.T., Ding Y., Griggs 
D.J., Noguer M., van der Linden P.J., Dai X., Maskell K., Johnson C.A. (Eds.), Contribution of Working Group I to the Third Assessment Report of the Intergovernmental Panel on Climate Change, Cambridge University Press, Cambridge, United Kingdom and New York, NY, USA, 2001.

[10] Kerr B.J., McKeith F.K., Easter R.A., Effects on performance and carcass characteristics of nursery to finisher pigs fed reduced crude protein, amino acids-supplemented diets, J. Anim. Sci. 73 (1995) 433-440.

[11] Le Bellego L., Noblet J., Van Milgen J., Effets de l'exposition au chaud et de la réduction du taux de protéines de l'aliment sur les performances du porc en croissance, $33^{\text {es }}$ Journées de la Recherche Porcine en France, Paris, France, 2001, pp. 189-195.

[12] National Research Council, Nutrient requirements of swine - Subcommittee on Swine Nutrition, Committee on Animal Nutrition, Board on Agriculture, National Research Council, 10th revised ed., National Academy of Science, Washington, DC, USA, 1998.

[13] Nicks B., Aspects environnementaux et zootechniques de l'élevage de porcs charcutiers et de porcelets sevrés sur litières accumulées de paille ou de sciure, Thèse de Doctorat, Université de Liège, Liège, 2004.

[14] Nicks B., Marlier D., Canart B., Comparaison des températures des litières et des niveaux de pollution de l'air lors de l'engraissement de porcs sur litières biomaitrisées à base de sciure ou de paille hachée, 26 ${ }^{\text {es }}$ Journées de la Recherche Porcine en France, Paris, France, 1994, pp. 85-90.

[15] Nicks B., Laitat M., Farnir F., Vandenheede M., Désiron A., Verhaeghe C., Canart B., Gaseous emissions from deep-litter pens with straw or sawdust for fattening pigs, Anim. Sci. 78 (2004) 99-107.

[16] Noblet J., Le Bellego L., Van Milgen J., Dubois S., Effects of reduced dietary protein level and fat addition on heat production and nitrogen and energy balance in growing pigs, Anim. Res. 50 (2001) 227-238.
[17] Otto E.R., Yokoyama M., Ku P.K., Ames N.K., Trottier N.L., Nitrogen balance and ileal amino acid digestibility in growing pigs fed diets reduced in protein concentration, $\mathrm{J}$. Anim. Sci. 81 (2003) 1743-1753.

[18] Pain B., Gaseous polluants from organic waste use in agriculture, in: RAMIRAN (Eds.), Report of the 8th international conference of the European cooperative research network on recycling of agricultural municipal and industrial residuals in agriculture, Rennes, France, 1998, pp. 233-246.

[19] Portejoie S., Martinez J., Landmann G., L'ammoniac d'origine agricole : impact sur la santé humaine et animale et sur le milieu naturel, INRA Prod. Anim. 15 (2002) 151160.

[20] Portejoie S., Dourmad J.Y., Martinez J., Lebreton Y., Effect of lowering dietary crude protein on nitrogen excretion, manure composition and ammonia emission from fattening pigs, Livest. Prod. Sci. 91 (2004) 45-55.

[21] SAS, SAS/STAT User's guide: Statistics (Version 8), SAS Inst. Inc., Cary, North Caroline, 1999.

[22] Sensi A., Agriculture et acidification, [Online] Available: http://europa.eu.int/ comm / agriculture / envir/report / fr/acid_fr/ report.htm (April 2005).

[23] Texier C., Élevage porcin et environnement, Institut Technique du Porc, Paris, 1997.

[24] Tuitoek K., Young L.G., de Lange C.F.M., Kerr B.J., The effect of reducing excess dietary amino acids on growing-finishing pig performance: an evaluation of the ideal protein concept, J. Anim. Sci. 75 (1997) 15751583.

[25] Zervas S., Zijlstra R.T., Effects of dietary protein and oathull fiber on nitrogen excretion patterns and postprandial plasma urea in grower pigs, J. Anim. Sci. 80 (2002) 3238 3246.

[26] Zervas S., Zijlstra R.T., Effects of dietary protein and fermentable fiber on nitrogen excretion patterns and plasma urea in grower pigs, J. Anim. Sci. 80 (2002) 3247-3256. 